\title{
Phytate-phosphorus and phytase contents on the relative weight of organs, intestinal morphometry and performance of broilers
}

\author{
Teores de fósforo fítico e fitase sobre o peso relativo de órgãos, \\ morfometria intestinal e desempenho de frangos de corte
}

\author{
Aiane Aparecida da Silva Catalan $^{\mathrm{I}^{*}}$ Everton Luis Krabbe $^{\mathrm{II}}$ Valdir Silveira de Avila ${ }^{\mathrm{II}}$ \\ Letícia dos Santos Lopes ${ }^{I I}$ Ana Paula Nunes ${ }^{I}$ Marcos Antonio Zanella Morés ${ }^{I I}$ \\ Victor Fernando Büttow Roll ${ }^{I}$ Eduardo Gonçalves Xavier ${ }^{I}$
}

\section{ABSTRACT}

In order to evaluate the efficiency of phytase in diets with low and high phytate phosphorus (PP) content, as a consequence of wheat bran inclusion, on the relative weight of organs, intestinal morphometry and performance, three hundred and eighty-four male Cobb500 broilers were housed in metabolic cages. Animals were assigned into four treatments in a $2 \times 2$ factorial scheme in a randomized block design with eight replicates of 12 birds each. From 11 days of age birds received experimental diets, which consisted of: Diet low in PP; Diet low in PP with phytase $\left(500 F T U \mathrm{~kg}^{-1}\right)$; Diet with a high PP and Diet with a high PP with phytase (500FTU $\left.\mathrm{kg}^{-1}\right)$. At 22 and 32 days of age two birds were slaughtered in order to collect gizzard, heart, liver, cecum, cloacal bursa, and at 32 days, a portion of the duodenum, jejunum and ileum was collected for morphometric evaluation. From 22 to 32 days of age average feed intake, average weight gain, average body weight and feed conversion ratio were also evaluated. Data were subjected to analysis of variance, fixed effects of diet and phytase and interaction between factors as well as the random block effects were tested. There was no significant interaction for the variables studied, concluding that phytase in diets with low or high phytate phosphorus content did not change the relative weight of organs, intestinal morphometrics and performance; only isolated effects were observed.

Key words: bird, enzyme, substrate, wheat bran.

\section{RESUMO}

Para avaliar a eficiência da fitase em dietas com baixo e alto teor de fósforo fítico (PP), em função da inclusão ou não do farelo de trigo, sobre o peso relativo de órgãos, morfometria intestinal e desempenho, foram alojados 384 frangos de corte, machos da linhagem Cobb500, em gaiolas metabólicas. Os animais foram distribuidos em quatro tratamentos em um arranjo fatorial $2 \times 2$ em delineamento de blocos casualizados com oito repetições e 12 aves por unidade experimental (UE).
A partir de 11 dias de idade as aves receberam as dietas experimentais, que consistiram em: Dieta com baixo teor de PP; Dieta com baixo teor de PP com fitase (500FTU $\mathrm{kg}^{-1}$ ); Dieta com alto teor de PP e Dieta com alto teor de PP com fitase (500FTU $\left.\mathrm{kg}^{-1}\right)$. Aos 22 e 32 dias de idade foram abatidas duas aves por UE para coletar a moela, coração, fígado, ceco, bolsa cloacal, e aos 32 dias foi coletada uma porção do duodeno, jejuno e íleo para avaliação da morfometria. No período de 22 a 32 dias de idade foram avaliados o consumo médio de ração, ganho de peso médio, peso médio corporal e a conversão alimentar. Os dados foram submetidos à análise de variância, onde foram testados os efeitos fixos de dieta e fitase e a interação entre os fatores, bem como o efeito aleatório de bloco. Não foi observada interação significativa para nenhuma das variáveis estudadas, concluindo-se que a fitase em dietas com baixo ou alto de PP não altera o peso relativo dos órgãos, a morfometria intestinal e o desempenho, apenas efeitos isolados foram observados.

Palavras-chave: ave, enzima, substrato, farelo de trigo.

\section{INTRODUCTION}

Although non-ruminants are fed with vegetal feed (cereals, oil seeds and their byproducts), approximately two thirds of the phosphorus present in such feed is in the PP form (GUENTER, 1997). Therefore, their diet must be complemented with inorganic phosphorus, one of the most expensive and rare minerals, as a greater part of that fraction of phosphorus not used is excreted with the feces, generating environmental pollution. In addition, it can combine with other ions, such as calcium, magnesium, zinc, iron, to form phytate and nutritional deficiencies

\footnotetext{
'Programa de Pós-graduação em Zootecnia, Universidade Federal de Pelotas (UFPEL), 96010-000, Pelotas, RS, Brasil. E-mail: aianec@yahoo.com.br. *Corresponding author.

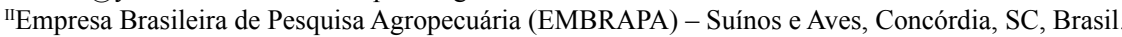
Received 06.18.15 Approved 04.04.16 Returned by the author 07.04.16 CR-2015-0892.R1
} 
(GUENTER, 1997; LEESON \& SUMMERS, 2005). However, non-ruminants have little or no capacity to utilize PP, as there is little or no natural synthesis of phytase enzyme in the digestive tract of these animals (GREINER \& KONIETZNY, 2010).

Exogenous enzymes are being broadly studied and used in animal nutrition with phytase being one of the most widely known. Phytase has an effect on performance, retention and availability of nutrients, reducing the variability of energy from feed stuffs, neutralizing the anti-nutritional effects of phytate; thus, increasing the accuracy of feed formulation (SOUSA et al., 2015).

The effects and benefits of phytase on the performance of broilers have been shown in different studies; however, phytase is basically used to reduce the anti-nutritional effects of phytate (RAVINDRAN et al., 2008; SELLE et al., 2009; OLUKOSI \&FRU-NJI, 2014; SOUSA et al., 2015). When such fact occurs, there is an improvement of intestinal integrity and consequently greater absorption of nutrients and better performance of the animal (SMULIKOWSKA et al., 2010).

To improve phytase efficacy, it is important to make available adequate substrate so that the enzyme may work accordingly. Wheat bran is a widely available and economically viable ingredient for use in animal feed, as it contains around $16 \%$ crude protein, $4.5 \%$ of fat content, $12 \%$ crude fiber (LEESON \& SUMMERS, 2005). This feed presents a high PP content, around $0.64 \%$, which represents $66 \%$ of total phosphorus contained in the raw material, and it may thus be considered a good substrate for the phytase enzyme (ROSTAGNO et al., 2011).

In this way, the aim of this study was to evaluate the efficiency of phytase on diets with low and high PP content and its effects on the relative weight of organs, intestinal morphometry and performance of broiler chicks.

\section{MATERIALS AND METHODS}

The study was conducted in a metabolic room under controlled temperature, relative humidity and illumination, according to the lineage manual (COBB500, 2009) at Embrapa Swine and Poultry. Three-hundred and eighty four 1-d old male Cobb500 broiler chicks were kept in metal metabolic cages, equipped with bar feeders and nipple drinkers, where feed and water were supplied ad libitum.

Birds were allocated into four treatments, resulting from a $2 \times 2$ factorial scheme (two levels of
PP x presence or absence of phytase 500FTU $\mathrm{kg}^{-1}$ ), in a randomized block design, with eight replicates per treatment and 12 birds per cage (experimental unit). At the beginning of the experiment, birds were weighed individually and sorted out into the blocks according to their initial weight, allowing all treatments to have eight blocks, which corresponded to replicates, with birds of uniform weight within each block, according to table 1 .

Diets were prepared so that they would have different levels of PP, one with low (corn and soybean meal) and another one with high PP content (corn and soybean meal with the inclusion of wheat bran). They were formulated according to the nutritional requirements for broiler chickens according to the Brazilian Table for Poultry and Swine (ROSTAGNO, et al., 2011), showing similar levels of metabolizable energy, crude protein, calcium, available phosphorus, sodium and digestible amino acids. Despite the inclusion of inert, wheat bran with high fiber content and vegetable oil, respecting the limits proposed by the literature, it was assumed that the levels were within the physiologically acceptable limits, to the point of not affecting animal performance and the evaluated responses.

Up to 10 days of age, all broilers were fed with the same basal diet. From the $11^{\text {th }}$ day on, two (11-21d and 22-32d) experimental diets were delivered that consisted in: T1 -low PP content diet; $\mathrm{T} 2$ - low PP content diet with phytase (500FTU kg ${ }^{-1}$ ); T3 - high PP content diet and T4 - high PP content diet with phytase (500FTU kg-1), according to table 2 .

A commercial phytase, produced from Aspergillus ficuum (3-phytase (EC 3.1.3.8)) was used. The phytase content in each feed was assessed following the method determined by ISO (2008) and the PP content was determined according to DE BOEVER et al. (1994), to determine the PP percentage obtained based on the molecular weight

Table 1 - Experimental blocks according to the weight of broilers in the housing.

\begin{tabular}{lc}
\hline Block & Average weight in the housing $(\mathrm{g})$ \\
\hline 1 & 51.3 \\
2 & 48.5 \\
3 & 46.9 \\
4 & 46.4 \\
5 & 44.9 \\
6 & 43.6 \\
7 & 42.6 \\
8 & 40.0 \\
\hline
\end{tabular}


Table 2 - Centesimal and nutritional composition of experimental diets for broilers.

\begin{tabular}{|c|c|c|c|c|c|c|c|c|c|}
\hline \multirow[b]{2}{*}{ Ingredients (kg) } & \multirow{2}{*}{$\begin{array}{c}\text { 1-10d } \\
\text { Basal Diet }\end{array}$} & \multicolumn{4}{|c|}{ 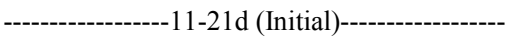 } & \multicolumn{4}{|c|}{ 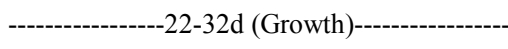 } \\
\hline & & $\begin{array}{c}\text { Low PP } \\
\text { NP* }^{*}\end{array}$ & $\begin{array}{c}\text { Low PP } \\
\mathrm{WP}^{* *}\end{array}$ & $\begin{array}{c}\text { High PP } \\
\text { NP }\end{array}$ & $\begin{array}{c}\text { High PP } \\
\text { WP }\end{array}$ & $\begin{array}{c}\text { Low PP } \\
\text { NP }\end{array}$ & $\begin{array}{c}\text { Low PP } \\
\text { WP }\end{array}$ & $\begin{array}{c}\text { High PP } \\
\text { NP }\end{array}$ & $\begin{array}{c}\text { High PP } \\
\text { WP }\end{array}$ \\
\hline Corn $(7.5 \%)$ & 50.7 & 63.9 & 63.9 & 48.7 & 48.7 & 72.4 & 72.4 & 52.9 & 52.9 \\
\hline Soybean meal $(45 \%)$ & 42.0 & 30.2 & 30.2 & 25.4 & 25.4 & 24.7 & 24.7 & 20.3 & 20.3 \\
\hline Wheat bran $(14 \%)$ & 0.0 & 0.0 & 0.0 & 20.0 & 20.0 & 0.0 & 0.0 & 20.0 & 20.0 \\
\hline Soybean oil & 3.1 & 0.0 & 0.0 & 2.9 & 2.9 & 0.0 & 0.0 & 4.4 & 4.4 \\
\hline Kaolin & 0.0 & 2.8 & 2.8 & 0.1 & 0.1 & 0.6 & 0.6 & 0.0 & 0.0 \\
\hline Dicalcium phosphate $^{1}$ & 1.8 & 1.0 & 1.0 & 0.8 & 0.8 & 0.8 & 0.8 & 0.5 & 0.5 \\
\hline Limestone $^{2}$ & 1.0 & 0.7 & 0.7 & 0.8 & 0.8 & 0.6 & 0.6 & 0.7 & 0.7 \\
\hline Iodized salt & 0.5 & 0.4 & 0.4 & 0.6 & 0.6 & 0.3 & 0.3 & 0.3 & 0.3 \\
\hline DL-melthionine & 0.3 & 0.2 & 0.2 & 0.2 & 0.2 & 0.2 & 0.2 & 0.2 & 0.2 \\
\hline L-lysine & 0.2 & 0.3 & 0.3 & 0.4 & 0.4 & 0.2 & 0.2 & 0.3 & 0.3 \\
\hline Vitamin premix ${ }^{3}$ & 0.1 & 0.1 & 0.1 & 0.1 & 0.1 & 0.1 & 0.1 & 0.1 & 0.1 \\
\hline Mineral premix ${ }^{4}$ & 0.05 & 0.05 & 0.05 & 0.05 & 0.05 & 0.05 & 0.05 & 0.05 & 0.05 \\
\hline L-threonine & 0.1 & 0.1 & 0.1 & 0.2 & 0.2 & 0.05 & 0.05 & 0.1 & 0.1 \\
\hline Phytase $^{5}$ & 0.00 & 0.00 & 0.05 & 0.00 & 0.05 & 0.00 & 0.05 & 0.00 & 0.05 \\
\hline TOTAL & 100 & 100 & 100 & 100 & 100 & 100 & 100 & 100 & 100 \\
\hline Metabolizable Energy $\left(\mathrm{kcal} \mathrm{kg}^{-1}\right)$ & 2950 & 2850 & 2850 & 2850 & 2850 & 3000 & 3000 & 3000 & 3000 \\
\hline Crude Protein (\%) & 23.0 & 18.6 & 18.6 & 18.6 & 18.6 & 16.5 & 16.5 & 16.4 & 16.4 \\
\hline Crude Fiber (\%) & - & 2.7 & 2.7 & 4.1 & 4.1 & 2.5 & 2.5 & 3.9 & 3.9 \\
\hline Ether Extract (\%) & - & 2.8 & 2.8 & 5.8 & 5.8 & 3.1 & 3.1 & 7.3 & 7.3 \\
\hline Calcium (\%) & 0.92 & 0.60 & 0.60 & 0.60 & 0.60 & 0.50 & 0.50 & 0.50 & 0.50 \\
\hline Sodium (\%) & 0.22 & 0.15 & 0.15 & 0.15 & 0.15 & 0.15 & 0.15 & 0.15 & 0.15 \\
\hline Digestible lysine & - & 1.10 & 1.10 & 1.10 & 1.10 & 0.89 & 0.89 & 0.90 & 0.90 \\
\hline Digestible methionine & - & 0.46 & 0.46 & 0.46 & 0.46 & 0.37 & 0.37 & 0.39 & 0.39 \\
\hline Available phosphorus (\%) & 0.47 & 0.30 & 0.30 & 0.30 & 0.30 & 0.25 & 0.25 & 0.25 & 0.25 \\
\hline Total phosphorus (\%) & 0.73 & 0.54 & 0.54 & 0.62 & 0.62 & 0.48 & 0.48 & 0.56 & 0.56 \\
\hline Calculated PP $(\%)^{6}$ & - & 0.24 & 0.24 & 0.32 & 0.32 & 0.24 & 0.24 & 0.31 & 0.31 \\
\hline Analyzed PP (\%) ${ }^{7}$ & - & 0.22 & 0.22 & 0.33 & 0.33 & 0.25 & 0.25 & 0.33 & 0.33 \\
\hline Added phytase & - & 0 & 500 & 0 & 500 & 0 & 500 & 0 & 500 \\
\hline Determined phytase $\mathrm{e}^{8,9}$ & - & 0 & 690 & 640 & 1315 & 135 & 725 & 330 & 1175 \\
\hline
\end{tabular}

${ }^{*} \mathrm{PP}$ NP - phytate phosphorus no phytase; ${ }^{* *} \mathrm{PP} \mathrm{WP}$ - phytate phosphorus with phytase: ${ }^{1} \mathrm{Calcium}: \operatorname{minimum~} 210 \mathrm{gkg}^{-1}$, maximum $250 \mathrm{gkg}{ }^{-1}$; Phosphorus: $180 \mathrm{gkg}^{-1} ;{ }^{2}$ Calcium: minimum 33\%; ${ }^{3}$ Levels of guarantee per product kg: Vitamin A: 9000000. 000UI, Vitamin D3: 2500000. 00UI, Vitamin E: 20000. 00UI, Vitamin K3: 2500. 00mg, Vitamin B1: 1500. 00mg, Vitamin B2: 6000. 00mg, Vitamin B6: 3000. 00mg, Vitamin B12:12000. 00mcg, Pantothenic Acid: 12g, Niacin: 25g, Folic Acid: 800. 00mg, Biotin: 60. 00mg, Selenium: 250. 00mg. ${ }^{4}$ Levels of guarantee per $\mathrm{kg}$ of product: Copper: 20g, Iron: 100g, Manganese: 160g, Cobalt: 2000. 00mg, Iodine: 2000. 00mg, Zinc: 100g. ${ }^{5}$ Natuphos, $10000 \mathrm{FTUg}^{-1} ;{ }^{6} \mathrm{Calculated}$ Phytate Phosphorus $=$ total phosphorus - available phosphorus. ${ }^{7}$ Levels obtained according to the report Enzyme Services and Consultancy - AB Vista; ${ }^{8}$ Level of phytase (FTU kg-1 of feed) according to the CBO Essay certificate - Lab analysis; ${ }^{9}$ The expected levels do not normally coincide with the supplemented levels because of the natural phytase present in the raw material, but it is assumed that natural phytase is not active in the gastrointestinal tract (GUENTER, 1997).

of six phosphorus molecules in relation to the molecular weight of the intact phytate molecule.

At 22 and 32 days of age, two birds per experimental unit were identified, weighed and sacrificed by cervical dislocation (ART.14 OF RESOLUTION No1000, CFMV, 2012) to collect gizzard, heart, liver, cecum, cloacal bursa to determine the relative weight of those organs. At 32 days, a portion of duodenum, jejunum and ileum was collected to assess their intestinal morphometry. The gizzard (without its content), heart, liver, cecum and cloacal bursa were weighed with a digital scale (Brand: Bel Engineering, model Mark 5200 and with 0,01g precision), to measure relative weight $(\% \mathrm{PR}=$ organ weight / body weight $\mathrm{x} 100$ ) in relation to the body weight of each bird at the time they were sacrificed.

In order to assess intestinal morphometry, a sample of two centimeters long of each of the 
segments of the thin intestine (duodenum, jejunum and ileum) was collected and then fixed in a $10 \%$ formaldehyde solution. After fixation, the samples were dehydrated in ascending concentrations (70, 80,90 and absolute) of ethyl alcohol, followed by diaphanization with xylol and inclusion in paraffin. Paraffin blocks were sectioned in rotating microtone at a thickness of $5 \mu \mathrm{m}$ in 10 transversal and semiserial cuts. Blades were stained with hematoxylin and eosin (HE), and then they were mounted between slides and cover slips using Entellan ${ }^{\circledR}$ resin (Merk). Histological sections were analyzed using digital images captured by a camera (Zeiss, Axio Cam ICc 3) coupled to a microscope (Zeiss, Scope A1) at $5 x$ magnification. Images were used to measure the heights of 10 villus and depths of 10 intestinal crypts and their measurement was made with a software program (Image Pro-Plus 4.5), and later relations between villus height and crypt depth were calculated. In the period of 22 to 32 days of age, birds were weighed for average body weight $(\mathrm{ABW})$ and average weight gain (AWG). Feed used and leftovers were also weighed during each phase to determine the average feed intake (AFI) and feed conversion ratio (FCR), which was obtained from the AFI/AWG.

Data were subjected to analysis of variance, with a $5 \%$ significance level through the SAS (2008) MIXED procedure. Fixed effects of diets and phytase, and interaction between factors, as well as randomized block effects, according to the statistical model were tested: $Y_{i j k}=\mu+B_{i}+D_{j}$ $+F_{k}+D F_{j k}+\varepsilon_{i j k}$, where, $Y_{i j k}=$ observed value in $i$-simal block, at $j$-simal phytate phosphorus content, at $k$-simal phytase level; $\mu=$ general mean; $B_{i}=$ block effect; $i=1,2, \ldots, 8 ; D_{j}=$ effect of phytate phosphorus content; $j=$ high, low; $F_{k}=$ effect of phytase level; $k=0,500 ; D F_{j k}=$ effect of interaction between phytate phosphorus content and phytase level; $\varepsilon_{i j k}=$ random error associated to each observation.

\section{RESULTS AND DISCUSSION}

Results of the relative weight of organs at 22 and 32 days of age did not show interaction between the PP and phytase factors (Table 3). However, at 32 days of age, there was an isolated

Table 3 - Relative weight (\%) of gizzard, heart, liver, cecum and cloacal bursa of broilers male Cobb 500 broilers, at 22 and 32 days of age, fed with low and high phytate phosphorus (PP) content diets and without or with phytase (mean \pm standard error).

\begin{tabular}{|c|c|c|c|c|c|c|c|}
\hline \multirow{3}{*}{ Age } & \multirow{3}{*}{ Variables $^{1}$} & \multirow{3}{*}{ PP } & \multicolumn{5}{|c|}{-----Phytase $\left(\mathrm{FTU} \mathrm{kg}^{-1}\right.$ )--------- $p$-value for the principal effect and interaction---- } \\
\hline & & & \multirow{2}{*}{0} & \multirow{2}{*}{500} & ----- & ffect------- & \\
\hline & & & & & PP & Phytase & Interaction \\
\hline \multirow{10}{*}{22 days } & \multirow{2}{*}{ Gizzard } & Low & $2.20 \pm 0.09$ & $2.15 \pm 0.05$ & \multirow{2}{*}{0.3254} & \multirow{2}{*}{0.2901} & \multirow{2}{*}{0.7110} \\
\hline & & High & $2.31 \pm 0.07$ & $2.19 \pm 0.09$ & & & \\
\hline & \multirow{2}{*}{ Heart } & Low & $0.477 \pm 0.01$ & $0.472 \pm 0.01$ & \multirow{2}{*}{0.8510} & \multirow{2}{*}{0.9436} & \multirow{2}{*}{0.6248} \\
\hline & & High & $0.473 \pm 0.02$ & $0.481 \pm 0.01$ & & & \\
\hline & \multirow{2}{*}{ Liver } & Low & $2.50 \pm 0.08$ & $2.55 \pm 0.09$ & \multirow{2}{*}{0.3299} & \multirow{2}{*}{0.2513} & \multirow{2}{*}{0.7058} \\
\hline & & High & $2.40 \pm 0.08$ & $2.51 \pm 0.10$ & & & \\
\hline & \multirow{2}{*}{ Cecum } & Low & $0.73 \pm 0.06$ & $0.74 \pm 0.05$ & \multirow{2}{*}{0.0534} & \multirow{2}{*}{0.5926} & \multirow{2}{*}{0.8347} \\
\hline & & High & $0.81 \pm 0.04$ & $0.84 \pm 0.04$ & & & \\
\hline & \multirow{2}{*}{ Cloacal bursa } & Low & $0.20 \pm 0.01$ & $0.20 \pm 0.02$ & \multirow{2}{*}{0.9389} & \multirow{2}{*}{0.8632} & \multirow{2}{*}{0.8858} \\
\hline & & High & $0.21 \pm 0.02$ & $0.20 \pm 0.01$ & & & \\
\hline \multirow{10}{*}{32 days } & \multirow{2}{*}{ Gizzard } & Low & $1.39 \pm 0.06$ & $1.51 \pm 0.06$ & \multirow{2}{*}{0.0109} & \multirow{2}{*}{0.1833} & \multirow{2}{*}{0.2903} \\
\hline & & High & $1.58 \pm 0.05$ & $1.60 \pm 0.06$ & & & \\
\hline & \multirow{2}{*}{ Heart } & Low & $0.42 \pm 0.01$ & $0.43 \pm 0.01$ & \multirow{2}{*}{0.0540} & 0.0398 & 0.4738 \\
\hline & & High & $0.38 \pm 0.02$ & $0.42 \pm 0.01$ & & 0.0390 & $0.4 / 50$ \\
\hline & Liver & Low & $2.25 \pm 0.05$ & $2.33 \pm 0.10$ & 00010 & 08581 & 03811 \\
\hline & Liver & High & $2.02 \pm 0.09$ & $1.96 \pm 0.06$ & 0.0010 & 0.0001 & 0.0011 \\
\hline & Сесum & Low & $0.70 \pm 0.04$ & $0.66 \pm 0.04$ & 02109 & 00346 & 01694 \\
\hline & cectin & High & $0.70 \pm 0.04$ & $0.54 \pm 0.05$ & 0.2109 & 0.0340 & 0.1094 \\
\hline & Cloacal bursa & Low & $0.22 \pm 0.02$ & $0.22 \pm 0.02$ & 0.5198 & 0.4845 & 06118 \\
\hline & & High & $0.21 \pm 0.01$ & $0.22 \pm 0.02$ & 0.0130 & $0.404 J$ & 0.0110 \\
\hline
\end{tabular}

\footnotetext{
${ }^{1}$ Averages obtained from eight replicates with two birds per experimental unit.
} 
effect both of PP content and of phytase. The diet with high PP content provided a greater relative weight for the gizzard and the diet with low PP content presented a greater relative weight for broiler chicks liver.

Regarding the diet with high PP content, it is also important to consider the high dietary fiber content, which according to MATEOS et al. (2012) may have effects on voluntary consumption, size of organs, intestinal motility, enzyme production and microbiota growth. It also resulted in greater development and better functioning of the gizzard, which may be an indication of the good functioning of the gastrointestinal tract.

When broilers were fed with a high phytate phosphorus diet, that is, with the inclusion of wheat bran, there was energetic dilution, which made necessary the inclusion of soybean oil in the diet to keep it isoenergetic. According to SILVA et al. (2014), replacing carbohydrate or protein with lipids implies in the reduction of the diet's calorie increase, which will make the liver work less due to a less complex enzymatic system for digestion and absorption of these molecules. This justifies the lesser relative weight observed in the liver.

The presence of phytase provided greater relative weight of the heart. Study conducted by WANG et al. (2013) did not observe such fact. However, SOUSA et al. (2015), upon evaluating diets with reduced nutritional levels, in the presence or absence of phytase, observed an increase in the relative weight of the heart, but with the absence of phytase. Authors noted that cardiac hypertrophy may be caused by hypophosphatemia due to the low supply of phosphorus. Nevertheless, in this study, there was no reduction of nutritional levels and the greater relative weight of the heart occurred with the presence of phytase, which would enable a greater phosphorus release, thus not characterizing a hypophosphatemia.

Birds' cecum had a smaller relative weight in the presence of phytase. HAN (1997) explains that the reduction of weight of the organs through the supplementation of exogenous enzymes may be related to the enzyme's efficiency in degrading anti-nutritive factors.

Table 4 presents the results of variables, villus height $(\mu \mathrm{m})$, crypt depth $(\mu \mathrm{m})$, and the

Table 4 - Villus height (VH), crypt depth (CD) and villus:crypt ratio (V:C) of duodenum, jejunum and ileum of broilers male Cobb 500 at 32 days of age, fed with low and high phytate phosphorus (PP) content diets and with or without phytase (mean \pm standard error).

\begin{tabular}{|c|c|c|c|c|c|c|c|}
\hline \multirow{3}{*}{ V } & & \multirow{3}{*}{ PP } & \multicolumn{2}{|c|}{ 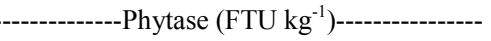 } & \multicolumn{3}{|c|}{$p$-value for the principal effect and interaction } \\
\hline & ables & & \multirow{2}{*}{0} & \multirow{2}{*}{500} & \multicolumn{2}{|c|}{--------Principal Effect---------- } & \multirow{2}{*}{ Interaction } \\
\hline & & & & & PP & Phytase & \\
\hline \multirow{6}{*}{$\mathrm{AV}(\mu \mathrm{m})$} & \multirow{2}{*}{ Duodenum } & Low & $1336.87 \pm 48.54$ & $1391.21 \pm 41.05$ & \multirow{2}{*}{0.5090} & \multirow{2}{*}{0.8823} & \multirow{2}{*}{0.1978} \\
\hline & & High & $1431.03 \pm 43.86$ & $1359.28 \pm 68.38$ & & & \\
\hline & \multirow{2}{*}{ Jejunum } & Low & $966.02 \pm 64.75$ & $947.86 \pm 72.99$ & \multirow{2}{*}{0.1994} & \multirow{2}{*}{0.6760} & \multirow{2}{*}{0.5403} \\
\hline & & High & $1019.16 \pm 50.99$ & $1096.04 \pm 99.80$ & & & \\
\hline & \multirow{2}{*}{ Ileum } & Low & $623.65 \pm 34.18$ & $699.12 \pm 41.82$ & \multirow{2}{*}{0.0670} & \multirow{2}{*}{0.3848} & \multirow{2}{*}{0.4283} \\
\hline & & High & $745.59 \pm 54.76$ & $749.14 \pm 50.83$ & & & \\
\hline \multirow{6}{*}{$\mathrm{CD}(\mu \mathrm{m})$} & \multirow{2}{*}{ Duodenum } & Low & $113.14 \pm 7.80$ & $113.57 \pm 8.26$ & \multirow{2}{*}{0.3588} & \multirow{2}{*}{0.1805} & \multirow{2}{*}{0.1709} \\
\hline & & High & $113.63 \pm 6.49$ & $99.86 \pm 3.60$ & & & \\
\hline & \multirow{2}{*}{ Jejunum } & Low & $126.34 \pm 8.29$ & $131.44 \pm 5.05$ & \multirow{2}{*}{0.5660} & \multirow{2}{*}{0.7110} & \multirow{2}{*}{0.6055} \\
\hline & & High & $133.61 \pm 3.81$ & $132.65 \pm 8.42$ & & & \\
\hline & \multirow{2}{*}{ Ileum } & Low & $110.10 \pm 5.20$ & $116.19 \pm 6.79$ & \multirow{2}{*}{0.2990} & \multirow{2}{*}{0.1980} & \multirow{2}{*}{08505} \\
\hline & & High & $114.78 \pm 4.99$ & $122.91 \pm 6.08$ & & & \\
\hline \multirow{6}{*}{ V:C Ratio } & Düdenum & Low & $12.73 \pm 0.77$ & $14.01 \pm 1.21$ & 03467 & 00671 & 08726 \\
\hline & Duvactintint & High & $13.26 \pm 1.15$ & $14.88 \pm 0.80$ & $0.340 /$ & $0.00 / 1$ & $0.8 / 20$ \\
\hline & Jeiunum & Low & $8.44 \pm 0.71$ & $7.60 \pm 0.65$ & 0.4516 & 09318 & 02914 \\
\hline & sejumum & High & $8.21 \pm 0.48$ & $8.93 \pm 0.92$ & 0.4510 & 0.9510 & 0.2914 \\
\hline & Ileum & Low & $6.01 \pm 0.29$ & $6.49 \pm 0.53$ & 03448 & 08875 & 03350 \\
\hline & Henin & High & $6.83 \pm 0.49$ & $6.48 \pm 0.30$ & $0.5+40$ & 0.0013 & 0.5500 \\
\hline
\end{tabular}

${ }^{1}$ Averages obtained from eight replicates with two birds per experimental unit. 
villi:crypt ratio in duodenum, jejunum and ileum of broilers, evaluated at 32 days of age. This study did not observe a significant interaction among the factors evaluated, nor their isolated effect. However, when WU et al. (2004) evaluated the influence of phytase on wheat-based diets with adequate levels of phosphorus, they determined that the villus of duodenum of the birds without phytase supplementation were relatively shorter and thicker. Whereas the addition of phytase provided an increase of the villus height when compared to the control treatment, but did not influence the villus height of the jejunum and ileum portion.

Evaluation of the intestinal morphological characteristics, such as villus height and crypt depth, is required due to the absorptive capacity of the intestinal mucosa because the higher the villus, greater is the area of contact of enterocytes with the feed, which increases the absorption area of nutrients. In addition, an adequate and rapid weight gain of birds is directly linked with the morphological and functional integrity of the digestive system (GOPINGER et al., 2014). Therefore, the inclusion of phytase in the diet of non-ruminants in order to reduce the antinutritional effects of phytate may also improve intestinal integrity and consequently improve nutrient absorption (SMULIKOWSKA et al., 2010).

Table 5 presents the results obtained for the performance in the period of 22 to 32 days of age, as there was no interaction among the factors analyzed because it is expected that when there is substrate (PP), the magnitude of the effect of the phytase enzyme is greater. However, when the effects were analyzed separately birds fed with a diet with higher PP content presented an AFI $1.64 \%$ greater in comparison with birds fed with a diet with low PP content. This is probably due to the high fiber content $(3.9 \%)$ supplied by the wheat bran. Increasing the fiber in the diet may provide a greater intestinal motility and, consequently increase passage rate, resulting in greater feed intake (MATEOS et al., 2012).

Phytase is well accepted in wheat-based diets (AMERAH, 2015); however, inclusion of wheat bran and phytase in broiler diets did not provide the best response for performance in this study. KLEYN (2013) notes that phytase has an impact mainly on the anti-nutritional properties of PP, and that, although not directly measurable, may have a positive effect on the performance of the birds due to a better absorption of the other nutrients. In addition, PP present in wheat is located in the aleurone and due to its fibrous nature it ends up limiting the access of the phytase to its substrate, thus stopping PP degradation (LIU et al., 2014).

\section{CONCLUSION}

Phytase and phytate phosphorus content did not interact for the variables of performance, intestinal morphometry and relative weight of organs in broiler up to 32 days of age. Nevertheless, the feed intake was affected by the phytate phosphorus content. In addition, the relative weight of gizzard, liver, heart and cecum were affected by both, presence of phytate and by presence of phytase separately.

Table 5 - Average feed intake (AFI - g/bird), average body weight (ABW- g/bird) on 32 days of age, and average weight gain (AWG $\mathrm{g} / \mathrm{bird}$ ) and feed conversion ratio (FCR - g:g) at the period of 22 to 32 days of age, for broilers male Cobb 500, fed with low and high phytate phosphorus (PP) content diets, and with or without phytase (mean \pm standard error).

\begin{tabular}{|c|c|c|c|c|c|c|}
\hline \multirow{3}{*}{ Variables $^{1}$} & \multirow{3}{*}{ PP } & \multicolumn{5}{|c|}{--------'Phytase FTU kg ${ }^{-1}$ )---------- } \\
\hline & & \multirow{2}{*}{0} & \multirow{2}{*}{500} & -.. & ffect------. & \multirow{2}{*}{ Interaction } \\
\hline & & & & PP & Phytase & \\
\hline \multirow{2}{*}{ AFI } & Low & $1395.17 \pm 15.29$ & $1390.27 \pm 20.23$ & \multirow{2}{*}{0.0319} & \multirow{2}{*}{0.9924} & \multirow{2}{*}{0.6266} \\
\hline & High & $1413.45 \pm 17.91$ & $1418.55 \pm 19.41$ & & & \\
\hline \multirow{2}{*}{$\mathrm{ABW}$} & Low & $1659.12 \pm 23.14$ & $1633.17 \pm 31.56$ & \multirow{2}{*}{0.0771} & \multirow{2}{*}{0.3948} & \multirow{2}{*}{0.6572} \\
\hline & High & $1613.69 \pm 23.43$ & $1605.45 \pm 20.59$ & & & \\
\hline \multirow{2}{*}{ AWG } & Low & $843.04 \pm 11.22$ & $830.51 \pm 22.89$ & \multirow{2}{*}{0.3221} & \multirow{2}{*}{0.4542} & \multirow{2}{*}{0.9323} \\
\hline & High & $856.74 \pm 17.69$ & $846.75 \pm 12.69$ & & & \\
\hline \multirow{2}{*}{ FCR } & Low & $1.656 \pm 0.013$ & $1.679 \pm 0.031$ & \multirow{2}{*}{0.8992} & \multirow{2}{*}{0.3056} & \multirow{2}{*}{0.9807} \\
\hline & High & $1.652 \pm 0.020$ & $1.677 \pm 0.025$ & & & \\
\hline
\end{tabular}




\section{BIOETHICS \\ AND COMMITTEE APPROVAL}

\section{BIOSECURITY}

Animal experiment procedures used in this study were approved by Ethics Committee in Animal Experimentation at Universidade Federal de Pelotas, under number 6866.

\section{REFERENCES}

AMERAH, A.M. Interactions between wheat characteristics and feed enzyme supplementation in broiler diets. Animal Feed Science and Technology, v.199, p.1-9, 2015. Accessed: Jun. 02, 2015. doi: 10.1016/j.anifeedsci.2014.09.012.

COBB500. Manual de manejo de frangos de corte Cobb. Arkansas: Cobb-Vantress, 2009.70p.

CFMV (CONSELHO FEDERAL DE MEDICINA VETERINÁRIA). Resolução $\mathrm{n}^{\circ} 1000$ de 11 de maio de 2012 . Dispõe sobre procedimentos e métodos de eutanásia em animais e dá outras providências. Brasília: Diário Oficial [da] República Federativa do Brasil, 2012. p.124-125.

DE BOEVER, J.L. et al. The possibilities of near infrared spectroscopy to predict total-phosphorus, phytate-phosphorus and phytase activity in vegetable feedstuffs. Netherlands Journal of Agricultural Science, v.42, p.357-369, 1994. Accessed: Jan. 08, 2015.

GREINER, R.; KONIETZNY, U. Phytases: biochemistry, enzymology and characteristics relevant to animal feed use. In: BEDFORD, M.R.; PARTRIDGE G.G. Enzymes in animal nutrition. Wallingford: CABI, 2010. p.96-128. Accessed: May 15, 2016.

GOPINGER, E. et al. The effect of different dietary levels of canola meal on growth performance, nutrient digestibility, and gut morphology of broiler chickens. Poultry Science, v.93, p.1130-1136, 2014. Accessed: Ago. 17, 2014. doi: $10.3382 /$ ps.2013-03426.

GUENTER, W. Phytases in cereals and hemicelluloses in canola (rapeseed) meal and lupins. In: MARQUARDT, R.R.; HAN, Z. Enzymes in poultry and swine nutrition. Ottawa: IDRC, 1997.p.99-114. Accessed: Dec. 21, 2014.

HAN, Z. Effect of enzyme supplementation of diets on the physiological function and performance of poultry. In: MARQUARDT, R.R.; HAN, Z. Enzymes in poultry and swine nutrition. Ottawa: IDRC, 1997.p.29-44. Accessed: Sept. 17, 2014.

ISO (INTERNATIONAL ORGANIZATION FOR STANDARDIZATION). Animal feeding stuffs determination of phytase activity. Geneva, 2008. 16p Accessed: Sept. 17, 2014

KLEYN, R. Enzymes in poultry nutrition. In: KLEYN, R. Chicken nutrition: a guide for nutritionists and poultry professional. Leicestershire, 2013. p.251-272.

LEESON, S.; SUMMERS, J.D. Ingredient evaluation and diet formulation: Description of ingredients - wheat by-products. In: LEESON, S.; SUMMERS, J.D. Commercial poultry nutrition. Guelph, 2005. p.25-27. Accessed: Ago. 17, 2014.
LIU, S.Y. et al. Effects of phytase supplementation on growth performance, nutrient utilization and digestive dynamics of starch and protein in broiler chickens offered maize-, sorghumand wheat-based diets. Animal Feed Science and Technology, v.194, p.164-175, 2014. Accessed: Dec. 03, 2014. doi: 10.1016/j. anifeedsci.2014.08.005.

MATEOS, G.G. et al. Poultry response to high levels of dietary fiber sources varying in physical and chemical characteristics. Journal Applied Poultry Research, v.21, p.156-174, 2012. Accessed: May. 30, 2014. doi: 10.3382/japr.2011-00477.

OLUKOSI, O.A.; FRU-NJI, F. The interplay of dietary nutrient specification and varying calcium to total phosphorus ratio on efficacy of a bacterial phytase: 1. Growth performance and tibia mineralization. Poultry Science, v.93, p.3037-3043, 2014. Accessed: Dec. 16, 2014. doi: 10.3382/ps.2014-03978.

RAVINDRAN, V. et al. Influence of dietary electrolyte balance and microbial phytase on growth performance, nutrient utilization, and excreta quality of broiler chickens. Poultry Science, v.87, p.677-688, 2008. Accessed: Feb. 02, 2015. doi: $10.3382 /$ ps.2007-0024.

SAS Institute. SAS user' sguide: statistics.Cary, NC, 2008.V.9.2.

SELLE, P.H. et al. Beneficial effects of xylanase and/or phytase inclusions on ileal amino acid digestibility, energy utilization, mineral retention and growth performance in wheat-based broiler diets. Animal Feed Science and Technology, v.153, p.303-313, 2009. Accessed: Jan. 14, 2015. doi: 10.1016/j. anifeedsci.2009.06.011

SILVA, J.H.V. et al. Digestão e absorção de lipídeos. In SAKOMURA et al. Nutrição de não ruminantes. Jaboticabal: FUNEP, 2014.p.466-484

SMULIKOWSKA, S. et al. Effect of an organic acid blend and phytase added to a rapeseed cake-containing diet on performance, intestinal morphology, caecal microflora activity, and thyroid status of broiler chickens. Journal of Animal Physiology and Animal Nutrition, v.94, p.15-23, 2010. Accessed: Jun. 02, 2015. doi: $10.1111 /$ j.1439-0396.2008.00876.x.

SOUSA, J.P.L. et al. The effect of dietary phytase on broiler performance and digestive, bone, and blood biochemistry characteristics. Revista Brasileira de Ciência Avícola, v.17, p.69-76, 2015. Accessed: May. 27, 2015. doi: 10.1590/1516$635 \times 170169-76$.

ROSTAGNO, H.S. et al. Brazilian tables for poultry and swines: food composition and nutrient requirements. Viçosa: UFV, 2011. 252p.

WANG, W. et al. Effects of phytase supplementation on growth performance, slaughter performance, growth of internal organs and small intestine, and serum biochemical parameters of broilers. Open Journal of Animal Science, v.3, p. 236-241, 2013. Accessed: Jan. 21, 2015. doi: 10.4236/ojas.2013.33035.

WU, Y.B. et al. Influence of phytase and xylanase, individually or in combination, on performance, apparent metabolisable energy, digestive tract measurements and gut morphology in broilers fed wheat-based diets containing adequate level of phosphorus. British Poultry Science, v.45, p.76-84, 2004. Accessed: Oct. 16, 2014. doi: 10.1080/00071660410001668897.

Ciência Rural, v.46, n.10, out, 2016. 